\title{
ACOUSTIC NEUROMA
}

\section{VESTIBULAR SCHWANNOMA}

\section{Surgical results on 240 patients operated on dorsal decubitus position}

\author{
Arquimedes Cavalcante Cardoso', Yvens B. Fernandes², \\ Ricardo Ramina², Guilherme Borges ${ }^{3}$
}

\begin{abstract}
Objective: To evaluate the result of the surgical treatment of vestibular schwannoma (VS) operated in dorsal decubitus (mastoid position). Method: 240 patients with a VS underwent a retrosigmoid craniotomy for tumor resection in dorsal decubitus (mastoid position). The function of $7^{\text {th }}$ and $8^{\text {th }}$ cranial nerves was monitored during surgery and the opened internal auditory canal (IAC) was reconstructed using a vascularized dura flap, muscle and fibrin glue. Results: Complete tumor removal was achieved in $99 \%$ of the cases, with a mortality of $1.6 \%$. The facial nerve function was preserved in $85 \%$ of cases and hearing in $40 \%$ of the patients (with preoperative hearing) with tumors of up $1.5 \mathrm{~cm}$ in diameter. The incidence of cerebrospinal fluid leak was $5.8 \%$ and meningitis $2.9 \%$. Venous air embolism was registered in $3 \%$ of cases; it was not associated to mortality. Conclusion: Surgical removal of VS in dorsal position has several advantages; the morbidity and mortality are very low.
\end{abstract}

KEY WORDS: acoustic neuroma, vestibular schwannoma, mastoid position, venous air embolism.

\section{Neurinoma do acústico (schwannoma do vestibular): resultados do tratamento cirúrgico de 240 pacientes operados na posição de decúbito dorsal}

RESUMO - Objetivo: Avaliar o resultado do tratamento cirúrgico de pacientes portadores de schwannoma do vestibular (SV) operados em decúbito dorsal (posição de mastóide). Método: 240 pacientes foram submetidos a craniotomia retrosigmóide na posição de mastóide. A função do VII e VIII nervos cranianos foi monitorizada durante a cirurgia e a reconstrução da abertura do conduto auditivo interno foi realizada com retalho vascularizado de dura-mater, músculo e cola de fibrina. Resultados: A exérese foi completa em $99 \%$ dos casos, com mortalidade de 1,6\%. Houve preservação da função do nervo facial em $85 \%$ dos casos e da audição em $40 \%$ dos pacientes com audição prévia e tumores menores de 1,5 cm. A incidência de fístula liquórica foi 5,8\% e meningite 2,9\%. Embolia gasosa foi registrada em 3\% dos casos, não associada à mortalidade. Conclusão: O tratamento cirúrgico dos SV utilizando-se a posição de mastóide tem várias vantagens, com baixa morbidade e mortalidade.

PALAVRAS-CHAVE: neurinoma do acústico, schwannoma vestibular, posição de mastóide, embolia gasosa.

The acoustic neuroma originates from the schwann cell, in the peripheral portion of superior and inferior vestibular nerves and also from cochlear nerve. These tumors are usually referred to as acoustic neuroma, but the preferred term to be used is vestibular schwannoma (VS), once they are composed of Schwann cells and more frequently are originated in the vestibular portion of the $8^{\text {th }}$ cranial nerve ${ }^{1}$. Patients diagnosed with VS often present unilateral hearing loss, tinnitus and dizziness ${ }^{2}$. The VS occurs in an incidence of about 1:100000 inhabitants per year. In most recent statistics an increase of such incidence has been reported due to frequent use of more sensitive magnetic resonance (MR) techniques, diagnosing very small tumors ${ }^{3}$. Currently radical surgical removal of the VS in a single surgery stage is the treatment of choice in most cases. However, despite important improvements in diagnosis and patient's information,

Departamento de Neurologia, Faculdade de Ciências Médicas, Universidade Estadual de Campinas, Campinas SP, Brasil (UNICAMP): ${ }^{1}$ Doutorando em Ciências Médicas; ${ }^{2}$ Professor Doutor; ${ }^{3}$ Livre-Docente Professor Associado. Supported by CNPq Grant \# 302189/2004-1.

Received 28 November 2006, received in final form 26 February 2007. Accepted 18 April 2007. 
the diagnosis of VS is still delayed in a great number of cases, and the tumors present a considerable size when a correct diagnosis is performed ${ }^{4,5}$. Three main surgical approaches: retrosigmoid-transmeatal (suboccipital), translabyrinthic and the middle cranial fossa or subtemporal have been used. Each one has both advantages and disadvantages, and excellent results have been reported with all these approaches $^{5-7}$.

Traditionally the suboccipital approach has been performed with the patient in a semi-sitting position. The sitting position for neurosurgical procedures has been a controversial subject among neurosurgeons and anesthesiologists. This position permits drainage of blood and cerebrospinal fluid (CSF) allowing a better visualization and dissection of the cranial nerves, easier hemostasia and reduces venous bleeding. The main disadvantages of this position are the increased risk of venous air embolism and hemodynamic instability, especially in elderly patients ${ }^{8-12}$.

The aim of this study was to evaluate the results of surgical treatment of VS in patients operated on through the retrosigmoid-transmeatal approach, in the dorsal decubitus position (mastoid position).

\section{METHOD}

In this study 240 consecutive patients with VS operated on at the Hospital das Clinicas - UNICAMP, SP and the Instituto de Neurologia de Curitiba, PR, between January 1990 and December 2005, were retrospectively evaluated. This study was approved by the Research Ethics Committee of both institutions.

In this study they were included 240 patients ( 238 with tumors sporadic, unilateral and 2 neurofibromatosis type 2 patients, operated of just one on the sides) operated on dorsal decubitus position (mastoid position) through the retrosigmoid-transmeatal approach (Fig 1). The age of the patients ranged between 16 and 81 years. No difference was observed regarding the gender or the side of the affected ear.



Fig 1. Dorsal decubitus (mastoid) position.
Tumor size was classified according to the Hannover grading system ${ }^{13}$ (Fig 2), in which tumor extension classes were described as follows: T1, purely intrameatal; T2, intraextrameatal; T3a, filling the cerebellopontine cistern; T3b, reaching the brainstem; $\mathrm{T} 4 \mathrm{a}$, compressing the brainstem; and $\mathrm{T} 4 \mathrm{~b}$, severely dislocating the brainstem and compressing the fourth ventricle.

The size of the lesions is demonstrated in Table 1.

Audiometric evaluation with discrimination computerized tomography (CT) and MR were performed in all cases before surgery. Intraoperative monitoring of facial nerve and cochlear nerve function was carried out by the group of neurophysiology. The facial nerve was monitored through electrodes put into the facial muscles (orbicularis occulli and oris) that were stimulated mechanically or electrically during dissection of the tumor. The cochlear nerve was monitored by recording evoked potentials of the brainstem ${ }^{5}$.

Besides routine neuroanaesthesia monitorization parameters an ultrasonic precordial Doppler sensor was used to detect venous air embolism and a right atrial catheter was placed to remove air bubbles if necessary.

Surgical technique - Retrosigmoid craniotomy with a diameter of about $5 \mathrm{~cm}$ was employed in all cases. The dura mater is opened parallel to the sigmoid and transversal sinuses. CSF is drained from the cerebellomedullary cistern to expose the cerebellopontine angle with minimal cerebellar retraction. The dura mater covering the internal auditory canal (IAC) is cut forming a dura flap attached over the jugular foramen region. This vascularized dura flap is used to cover the cranial nerves and reconstruct the IAC at the end of surgery. Microsurgical tumor excision with use of microsurgical instruments, preserving the arachnoid plane to preserve the cranial nerves, brain stem and vessels was the surgical technique used. Bipolar coagulation is careful utilized to avoid cranial nerves injury by heating. After total resection of the tumor and careful hemostasia, the IAC is covered by the dura flap and a piece of muscle and fibrin glue is placed over it to avoid CSF leak. The dura is sutured with running stitches and covered with surgicel and fibrin glue. The bone flap is replaced, the subcutaneous tissue and the skin are closed with separated sutures.

Patients were evaluated regarding clinical and surgical complications: related to positioning, detection of ve-

Table 1. Size of the tumor, according to the Hannover classification.

\begin{tabular}{ccc}
\hline Size & $\mathrm{N}$ & $\%$ \\
\hline T1 & 12 & 5.00 \\
T2 & 41 & 17.08 \\
T3 a & 21 & 8.75 \\
T3 b & 24 & 10.00 \\
T4 a & 63 & 26.25 \\
T4 b & 79 & 32.92 \\
Total & 240 & 100 \\
\hline
\end{tabular}




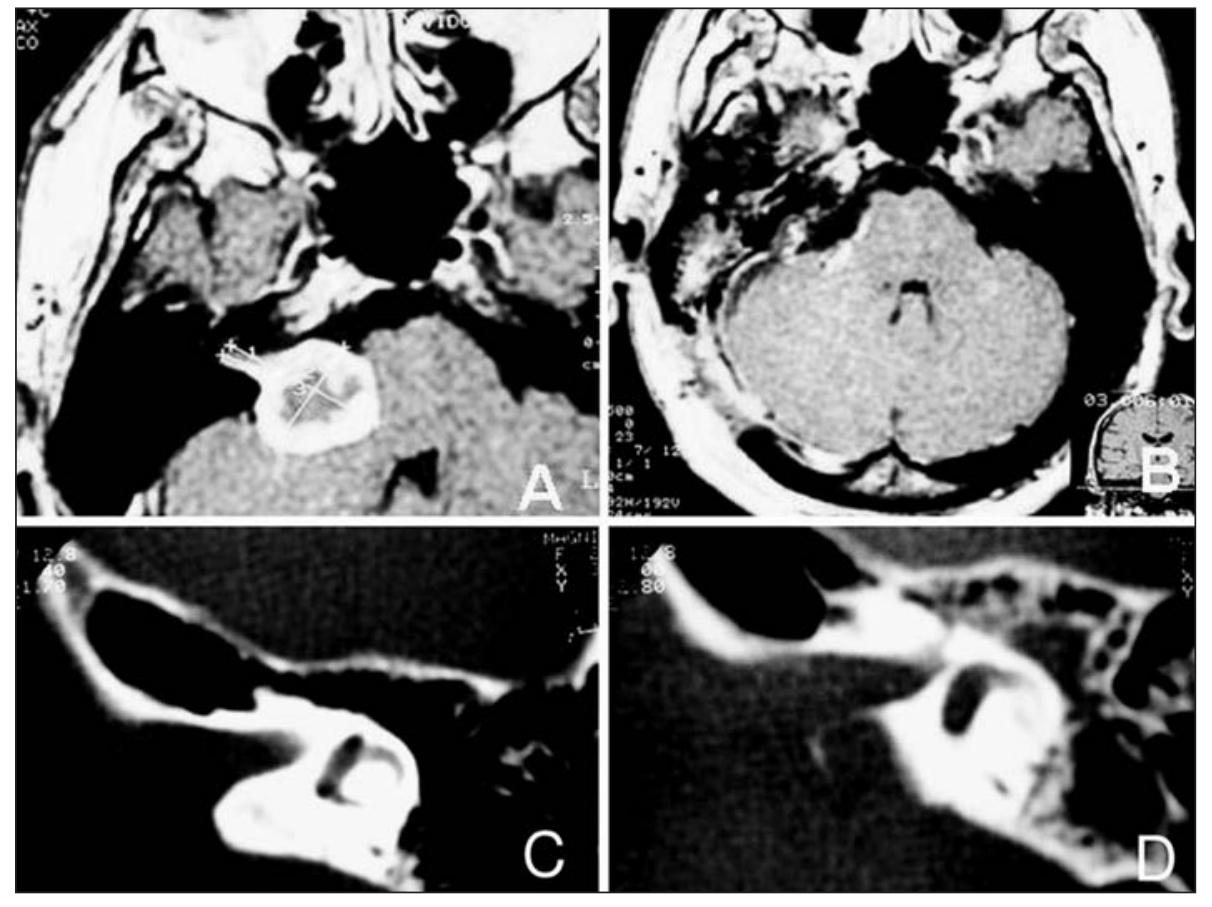

Fig 2. MRI scans showing a T4a VS ${ }^{13}$ : (A) preoperative; (B) postoperative. CT scan: (C) preoperative; (D) 24hours after surgery, showing the opening of the IAC. nous air embolism and its effects, presence of CSF leak and meningitis and preservation of the cranial nerve's function. The function of the facial nerve was evaluated through the scale of House and Brackmann ${ }^{14}$ and the auditory function through the audiometric classification of Hannover ${ }^{4}$. All patients had a postoperative MR on average 4 months after surgery.

\section{RESULTS}

Most patients presented tumors larger than $3.0 \mathrm{~cm}$ in (166 cases). The function of the facial nerve could be preserved in $85 \%$ of patients with preoperative facial function, regardless the size of the lesion (Grades 1 to 3 House and Brackmann) ${ }^{14}$. In patients with tumors smaller than $3.0 \mathrm{~cm}$ in diameter preservation of the facial nerve function was possible in $100 \%$ of the cases. Hearing preservation was possible in 8 (40 \%) of the 20 patients with preoperative hearing with tumors of up to $1.5 \mathrm{~cm}$ in diameter.

Four patients died in these series (1.6\%). Three patients presented large tumors, $5.0 \mathrm{~cm}$ in diameter (T4b). Mortality was caused by a hematoma in the tumor bed in two cases and thrombosis of the basilar artery in the other two. Causes of basilar artery thrombosis were damage to the vertebral artery during dissection at $\mathrm{C} 1-\mathrm{C} 2$ region in one of the patients and inadequate positioning with exaggerated head rotation in the other patient.

Cerebrospinal fluid leak occurred in 14 patients $(5.8 \%)$. Seven $(2.9 \%)$ developed meningitis, treated with antibiotics. Compressive dressing and lumbar drainage was used to treat the CSF fistula. Surgical closure of CSF leak was necessary in 5 patients.

Postoperative control MR was carried out in all cases, the facial nerve function was evaluated and when the cochlear nerve could be preserved the hearing function was tested. Total removal of the lesion was obtained in 238 cases (99\%). In two cases of cystic tumors the control MR revealed recurrence of the lesion.

In this series 36 patients had postoperative lesion of the facial nerve. In two of them suture of the stumps of the facial nerve was accomplished in the same surgical act and the remaining of the patients was submitted to a facial-hypoglossal nerve anastomosis. 16 patients with anatomical lesion were operated among 7-10 days after the surgery and in 18 patients with preservation of the facial nerve, however with facial paralysis, the reconstruction was accomplished 1 year after the surgery. A functional improvement (grade 3 or 4) was postoperatively observed in all these patients.

The incidence of venous air embolism detected through Doppler was 3\%, however, it was not associated with morbidity or mortality in this series. Excluding the patient with vertebral artery lesion, no further complications were related to the positioning of the patient.

\section{DISCUSSION}

The centers with extensive experience in the sur- 
Table 2. Semi-sitting $X$ dorsal position, advantages and disadvantages.

\begin{tabular}{lcc}
\hline Position & Semi-sitting & Dorsal \\
\hline Dificulty and time needed to positioning & $\begin{array}{c}\text { Difficult specially in obese } \\
\text { patients, more time needed }\end{array}$ & $\begin{array}{c}\text { Easy, fast positioning, } \\
\text { rotation of surgical table } \\
\text { For the surgeon }\end{array}$ \\
$\begin{array}{l}\text { Not confortable } \\
\text { Posterior fossa exposure }\end{array}$ & Excellent & More confortable \\
Cerebellar retraction & Minimal & Minimal \\
Surgical field & Good CSF and blood drainage & Continuous CSF and blood aspiration \\
Cranial nerves dissection at brain stem & Very good & Good \\
Cranial nerves dissection within IAC & Good & Very good \\
IAC fundus exposure & Very good & Very good \\
Cardiocircullatory disturbances & May occur specially in & Very infrequent \\
Incidence of air embolism & elderly patients & Not frequent \\
Quadriparesis, hipertensive pneumocephalus & Frequent & Very rare \\
Postoperative venous bleeding & Several cases reported & Very rare
\end{tabular}

References: 8,9,10,11,12,14,22,23.

gery of VS generally opt for four categories of surgical access: (1) suboccipital access, (2) translabyrinthic access, (3) middle cranial fossa access and (4) eclectic access. Excellent results have been published by the use of these four approaches ${ }^{15-21}$.

In our series the retrosigmoid-transmeatal access was used in all patients. According to our experience this approach allows an adequate exposure to VS of all sizes, is quickly performed, permits preservation of hearing, easy identification of the facial nerve inside the IAC, adequate controlling of vascular and nervous structures of the posterior cranial fossa and brainstem and primary closure of dura mater ${ }^{22}$.

The positions used for resection of the VS through the retrosigmoid-transmeatal access are: semi-sitting, ventral and park bench. The position that we use in this study is dorsal with the patient's head turned in order to expose the posterior cranial fossa and the mastoid. The advantages of this position are related to the easy of positioning, to avoid hemodynamic instability, the comfort of the surgeon and the significant reduction of the risk of venous air embolism. These advantages are present principally regarding the semi-sitting position, despite there being several proponents of this last position ${ }^{16,22,23}$.

The sitting position has been controversial since it was first introduced by De Martel in Paris, in 1913, to operate a brain tumor surgery with local anesthesia. Due to hydrostatic gravity effect, an accumulation of blood in the extremities as high as $1500 \mathrm{~mL}$ occurs producing systemic decrease in blood pressure ${ }^{8}$. This position makes the surgical field clear of blood and
CSF. The most feared complication of this position is venous air embolism. Air embolism may occur in any operation with an open vein and a gradient of venous pressure between the surgical site and the heart ${ }^{8-12}$. The incidence in the horizontal position is, however, lower.

Series comparing the prognosis of patients operated on in sitting and horizontal position, conclude that despite the venous air embolism being an important factor in surgery of posterior cranial fossa, the current methods of monitoring allow an early detection and prompt therapy of venous air embolism $^{12,23}$. Nevertheless, we have to consider that not all departments have such modern methods of monitoring. The incidence of complications of right atrial catheter may be high and the volume of air removed through it can be minimal ${ }^{9-12,23}$.

There are other potential complications associated with the position of the patient during the VS surgery. Orthopedic, peripheral nerve and cutaneous lesions, have been described in all surgical procedures and may be avoided with careful positioning of the patient ${ }^{23}$. Other reasons to avoid the sitting position are the risk of quadriparesis, increased risk of hypertensive pneumocephalus, post-operative bleeding, tongue and larynx edema $a^{8,9,23}$. The advantages and disadvantages ${ }^{8-12,14,22,23}$ of both positions are showed on Table 2.

The main goals of the surgery include complete excision of the lesion in one stage, without mortality and preservation of the neurological function, especially of the $7^{\text {th }}$ nerve and hearing. 
In this series the tumor was larger than $3.0 \mathrm{~cm}$ in most patients (166 cases). The facial nerve function could be preserved (Grades 1 to 3 House and Brackmann $)^{14}$ in $85 \%$ of patients with preoperative facial function, regardless of the size of the lesion. In patients with tumors smaller than $3.0 \mathrm{~cm}$ in diameter, the preservation of the facial nerve occurred in $100 \%$ of the cases. These data are comparable with results published by very experienced authors ${ }^{15-19,24}$.

Early diagnosis of small and intracanicular VS has increased due improvement of radiological diagnostic methods. Often these patients present useful hearing of the side affected by the tumor making hearing preservation an objective of treatment. There are also some reports of hearing preservation in large tumors ${ }^{4,17-19,25,26}$

Our strategy is to try to preserve the cochlear nerve and hearing in every case with preoperative cochlear nerve function. Even the hearing classified as non useful is still many times superior to that one obtained with cochlear implants and it is far superior to that obtained with brain stem implants. It is also possible that preservation of cochlear nerve will in the future, with new technology, allow patients to recover hearing ${ }^{5,22}$.

CSF leak and its association with the risk of meningitis remain as important issues in the surgical treatment of VS. An incidence between 0 and $30 \%$, with an approximate rate of $12 \%$ is reported ${ }^{27}$. With the use of fibrin glue and reconstruction of the IAC with dura mater flap and muscle filling, we were able to reduce the incidence of CSF fistula in comparison with previous report ${ }^{27}$.

In the last 20 years, radiosurgery and stereotatic radiosurgery have been used to treat VS as a less invasive alternative to the surgical treatment. Some authors regard it as the first option to tumors smaller than $3 \mathrm{~cm}^{2,28}$. No tumor can be cured with this method and the objective of treatment is to obtain "control of tumor growth". In our opinion, radiotherapy/ radiosurgery should be only exceptionally indicated in elderly patients or patients without clinical condition for radical removal and cure of this benign tumor.

\section{REFERENCES}

1. Roswell E, Dilys P. Summary: vestibular schwannomas (acoustic neuroma). Consensus Development Conference. Conference Proceedings. Neurosurgery 1992;30:962-964.

2. Pollock BE, Driscoll CLW, Foote RL, et al. Patient outcomes after vestibular schwannoma management: a prospective comparison of microsurgical resection and stereotactic radiosurgery. Neurosurgery 2006;1: 77-85.
3. Haines SJ, Levine SC. Intracanalicular acoustic neuroma:early surgery for preservation of hearing. J Neurosurg 1993;79:515-520.

4. Matthies C, Samii M. Vestibular schwannomas and auditory function: options in large T3 and T4 tumors? Neurochirurgie 2002;48:461-470.

5. Ramina R, Fernandes YB, Borges G, et al. Neurinoma do acústico (schwannoma do vestibular). Tópicos em Neurocirurgia. Rio de Janeiro: Revinter, 2001:59-64.

6. Ojemann RG. Management of acoustic neuromas (vestibular schwannomas). Clin Neurosurg 1993;40:498-535.

7. Koerbel A, Gharabaghi A, Safavi-Abbasi S, Tatagiba M, Sammi M. Evolution of vestibular schwannoma surgery: the long journey to current success. Neurosurg Focus 2005;18:24.

8. Albin MS, Babinski M, Maroon JC, Jannetta PJ. Anesthetic management of posterior fossa surgery in the sitting position. Acta Anaesth Scand 1976;20:117-128.

9. Standefer M, Bay JW, Trusso R. The sitting position in neurosurgery: a retrospective analysis of 488 cases. Neurosurgery 1984;14:649-658.

10. Matjasko J, Petrozza P, Cohen M, Steinberg P. Anesthesia and surgery in the seated position: analysis of 554 cases. Neurosurgery 1985; 17: 695-702.

11. Young ML, Smith DS, Murtagh F, Vasquez A, Levitt J. Comparison of surgical and anesthetic complications in neurosurgical patients experiencing venous air embolism in the sitting position. Neurosurgery 1986;18:157-161

12. Duke DA, Lynch JJ, Harner SG, Faust RJ, Ebersold MJ. Venous air embolism in sitting and supine patients undergoing vestibular schwannoma resection. Neurosurgery 1998;42:1282-1287.

13. Matthies C, Samii, M. Management of 1000 vestibular schwannomas (acoustic neuromas): clinical presentation. Neurosurgery 1997;40: $1-10$.

14. House JW, Brackmann DE. Facial nerve grading system. Otolaryngol Head Neck Surg 1985;93:146-147.

15. Siqueira JM, Souza OG. Preservation of the facial nerve in large acoustic neuromas using the combined translabyrinthine-subocciptal approach Arq Bras Neurocirurg 1992;11:77-80.

16. Samii M, Matthies C. Management of 1000 vestibular schwannomas (acoustic neuroma): surgical management and results with an emphasis on complications and how to avoid them. Neurosurgery 1997;40: $11-23$.

17. Bento RF, Miniti A, Bogar P. Experiência em 115 casos de cirurgia para exérese de neurinoma do acústico. Rev Bras Otorrinolaringol 1995; 61:204-217.

18. Ebersold MJ, Harner SG, Beatty CW, Harper Jr CM, Quast LM. Current results of the retrosigmoid approach to acoustic neurinoma. J Neurosurg 1992;76:901-909.

19. Ojemann RG. Retrosigmoid approach to acoustic neuroma (vestibular schwannoma). Neurosurgery 2001;48:553-558.

20. Day JD, Chen DA, Arriaga M. Translabyrinthine approach for acoustic neuroma. Neurosurgery 2004;54:391-396.

21. Sanna M, Russo A, Falcioni M, Taibah A, Agarwal, M. Enlarged translabyrinthine approach for the management of large and giant acoustic neuromas: a report of 175 consecutive cases. Ann Otol Rhinol Laryngol 2004;113:319-328.

22. Ramina R, Maniglia JJ, Meneses MS, et al. Acoustic neurinomas diagnosis and treatment. Arq Neuropsiquiatr 1997;55:393-402.

23. Black S, Ockert DB, Oliver Jr WC, Cucchiara RF. Outcome following posterior fossa craniectomy in patients in the sitting or horizontal positions. Anesthesiology 1988;69:49-56.

24. Wiegand DA, Fickel V. Acoustic neuroma: the patient's perspective: subjective assessment of symptoms, diagnosis, therapy and outcome in 541 patients. Laryngoscope 1989;99:179-187.

25. Gardner G, Robertson JH. Hearing preservation in unilateral acoustic neuroma surgery. Ann Otol Rhinol Laryngol 1988;97:55-66.

26. Silveira RL, Gusmão SNS, Ferraz FAP, Cabral G Filho, Tazinaffo U. Perspectivas atuais sobre a preservação da audição na cirurgia do neurinoma do acústico. J Bras Neurocirurg 1996;7:5-18.

27. Brennan JW, Rowed DW, Nedzelski JM, Chen JM. Cerebrospinal fluid leak after acoustic neuroma surgery: influence of tumor size and surgical approach on incidence and response to treatment. J Neurosurg 2001;94:217-233.

28. Kondziolka D, Nathoo N, Flickinger JC, Niranjan A, Maitz AH, Lunsford LD. Long-term results after radiosurgery for benign intracanial tumors. Neurosurgery 2003;53:815-822. 